\title{
Stable isotope analyses differentiate between different trophic pathways supporting rocky-reef fishes
}

\author{
Carrie J. Thomas, Lawrence B. Cahoon \\ Biological Sciences, University of North Carolina at Wilmington, Wilmington, North Carolina 28403, USA
}

\begin{abstract}
Stable isotope analyses of 5 reef-associated fishes, Decapterus punctatus, Diplodus holbrooki, Rhomboplites aurorubens, Pagrus pagrus, and Haemulon aurolineatum, were conducted to determine the ability of stable isotope analysis to distinguish among the species and the trophic pathways that support them. Analyses of $\delta^{13} \mathrm{C}, \delta^{15} \mathrm{~N}$, and $\delta^{34} \mathrm{~S}$ from white swimming muscle yielded significant differences between species. Multiple stable isotope signatures of these 5 species indicated that at least 2 trophic pathways, one planktonic and one benthic, supported these reef-associated species. Variability of isotopic signatures within species was largely a result of collection site differences. $\delta^{3} \mathrm{C}$ and $\delta^{15} \mathrm{~N}$ values indicated that all fishes were feeding at similar trophic levels. $\delta^{34} \mathrm{~S}$ values proved to be useful supplements to carbon and nitrogen isotope values in separating species by signature.
\end{abstract}

\section{INTRODUCTION}

Total primary production on the continental shelf off North Carolina, USA, is supported by 3 sources: phytoplankton, benthic macroalgae, and benthic microalgae. Cahoon et al. (1990) found benthic microalgal biomass frequently equalled or exceeded integrated phytoplankton biomass across the shelf. Phytoplankton and benthic microalgal production are similar in Onslow Bay (Cahoon \& Cooke 1992). Benthic macroalgae are distributed across the shelf attached to hard substrates, rock outcrops (Schneider 1976) and artificial reef systems. All 3 sources of production support reef communities on the shelf.

Several species of reef-associated fishes are thought to be important links between these primary producers and top carnivores in the North Carolina continental shelf ecosystem. Gut content analyses of several reeffish species show that each kind of primary producer supports a distinct food chain that includes 1 or more common reef-associated fish species. Hales (1987) and Donaldson (1991) found holozooplankton to be the primary food item of Decapterus punctatus (round scad). D. punctatus often aggregates near hard bottom areas and feeds directly above reefs and over nearby sandy areas (Hales 1987. Donaldson 1991). Other fishes, such as Diplodus holbrooki (spottail pinfish), feed upon benthic macroalgae and associated invertebrates (Hay \& Sutherland 1988, Pike 1991). Finally, demersal zooplankton feed on benthic microalgae (Tronzo 1989). Demersal zooplankton are in turn a food item for fishes such as Haemulon aurolineatum (tomtate) (Bolden 1990). Reef-associated fishes such as Rhomboplites aurorubens (vermilion snapper) and Pagrus pagrus (red porgy) forage in the water column for nekton and for reef-associated benthic invertebrates, respectively (Manooch 1977, Grimes 1979).

Results of gut content analyses indicate feeding behavior and ultimately food sources, but they do not provide information about assimilation of food or necessarily identify the primary producers supporting each species. Stable isotope analyses provide a method for the determination of original sources of organic nutrients (Deniro \& Epstein 1978, Rau et al. 1983, Fry 1984) because, unlike gut content analyses, they are related directly to assimilation.

Multiple stable isotope analyses were used to test the hypotheses that: (1) multiple stable isotope analyses distinguish among 5 reef-associated fish species: Decapterus punctatus, Pagrus pagrus, Rhomboplites 
aurorubens, Diplodus holbrooki and Haemulon aurolineatum, and (2) these differences correspond to differences in the food chains supporting these fishes.

\section{METHODS}

Fishes were collected with hook and line, trawl, or microbarb spear. Some were also obtained from commercial fishermen. Fishes were collected from Onslow and Long Bays during 1990 and 1991. Study sites included 3 natural limestone reefs called the ' 5 mile site', the ' 23 mile site', and the ' 38 mile site' $(8,37$, and $61 \mathrm{~km}$ offshore, respectively) and areas near the shelf edge. Fishes were immediately placed on ice after collection. Fishes were measured and filleted as soon as possible. Fillets and remaining parts were then frozen until prepared for isotopic analysis.

White swimming muscle was used for all analyses. Muscle turnover rates are longer than those of liver and blood (Tieszen et al. 1983, B. Fry pers. comm.), and thus integrate diet over months. Muscle tissue was lyophilized and ground to a fine powder. This powder was used directly for carbon and nitrogen analyses. A portion of the dried flesh was used for sulfur analysis after removal of inorganic sulfates with a series of 3 deionized water rinses.

Isotopic analyses of ${ }^{13} \mathrm{C}:{ }^{14} \mathrm{C},{ }^{15} \mathrm{~N}:{ }^{14} \mathrm{~N}$, and ${ }^{34} \mathrm{~S}:{ }^{32} \mathrm{~S}$ were conducted by Dr Brian Fry at the Ecosystems Center at the Marine Biological Laboratory in Woods Hole, Massachusetts, USA. Isotopic composition was measured on an automated Delta S mass spectrometer. Isotope values were expressed as $\delta^{13} \mathrm{C}, \delta^{15} \mathrm{~N}$, or $\delta^{34} \mathrm{~S}$ relative to Pee Dee Belemnite for carbon analyses, air for nitrogen analyses, and Canyon Diablo troilite for sulfur analyses. Delta values were determined as follows:

$$
\delta X=\left[\frac{R_{\text {sample }}}{R_{\text {standard }}}-1\right] \times 10^{3}
$$

where $X=$ the rare isotope $\left({ }^{13} \mathrm{C},{ }^{34} \mathrm{~S}\right.$, or $\left.{ }^{15} \mathrm{~N}\right)$ and $R=$ ${ }^{13} \mathrm{C}:{ }^{12} \mathrm{C}_{1}{ }^{34} \mathrm{~S}:{ }^{32} \mathrm{~S}$, or ${ }^{15} \mathrm{~N}:{ }^{14} \mathrm{~N}$.

Seventy-nine fishes were analyzed for carbon, nitrogen, and sulfur isotope composition. An additional 21 fishes were analyzed for carbon and nitrogen isotope composition. At least 2 replicates of every classification variable combination (species $\times$ size class $\times$ month $\times$ location) were completed. Individuals from each species from at least 2 locations, 2 size classes, and 2 seasons were analyzed as fish availability allowed. Haemulon aurolineatum was an exception; only 6 individuals collected on the same day at 1 location were isotopically analyzed (Table 1).

SAS multiple analysis of variance (MANOVA) using the general linear model procedure (GLM) (SAS Institute
Table 1. Explanation of classification variables for each species of fish used in isotope analyses. Size class ranges are given in $\mathrm{mm}$ standard length (SL). Locations: L, Long Bay;

$O$, Onslow Bay; OL, Onslow and Long Bays

\begin{tabular}{|c|c|c|c|}
\hline Species & $\begin{array}{l}\text { Size class } \\
(\mathrm{mm} \mathrm{SL})\end{array}$ & Month & Location \\
\hline \multirow[t]{2}{*}{$\begin{array}{l}\text { Round } \\
\text { scad }\end{array}$} & 1: $104-143$ & $\begin{array}{l}\text { Mar } \\
\text { Jun } \\
\text { Jul } \\
\text { Sep } \\
\text { Oct } \\
\text { Nov }\end{array}$ & $\begin{array}{l}5 \text { mile } \\
5 \text { mile } \\
\text { Shelf edge, L } \\
23 \text { mile } \\
\text { Shelf edge, L } \\
\text { Shelf edge, L }\end{array}$ \\
\hline & 2: $144-183$ & $\begin{array}{l}\text { Jun } \\
\text { Jul } \\
\text { Oct } \\
\text { Nov }\end{array}$ & $\begin{array}{l}5 \text { mile } \\
\text { Shelf edge, L } \\
\text { Shelf edge, OL } \\
\text { Shelf edge, L }\end{array}$ \\
\hline \multirow[t]{2}{*}{$\begin{array}{l}\text { Spottail } \\
\text { pinfish }\end{array}$} & $1: 91-157$ & $\begin{array}{l}\text { May } \\
\text { Jun } \\
\text { Jul } \\
\text { Sep }\end{array}$ & $\begin{array}{l}5 \text { mile } \\
5 \text { mile } \\
5 \text { and } 23 \text { mile } \\
23 \text { mile }\end{array}$ \\
\hline & 2: $158-223$ & $\begin{array}{l}\text { May } \\
\text { May } \\
\text { Jul } \\
\text { Sep } \\
\text { Oct }\end{array}$ & $\begin{array}{l}5 \text { mile } \\
\text { Shelf edge, } L \\
\text { Shelf edge, O } \\
23 \text { mile } \\
23 \text { mile }\end{array}$ \\
\hline \multirow[t]{2}{*}{$\begin{array}{l}\text { Vermilion } \\
\text { snapper }\end{array}$} & 1: $159-234$ & $\begin{array}{l}\text { May } \\
\text { Jun } \\
\text { Aug } \\
\text { Sep }\end{array}$ & $\begin{array}{l}\text { Shelf edge, L } \\
\text { Shelf edge, L } \\
\text { Shelf edge, O } \\
\text { Shelf edge, O }\end{array}$ \\
\hline & 2: $235-310$ & $\begin{array}{l}\text { Jun } \\
\text { Sep }\end{array}$ & $\begin{array}{l}\text { Shelf edge, O } \\
\text { Shelf edge, O }\end{array}$ \\
\hline \multirow[t]{2}{*}{$\begin{array}{l}\text { Red } \\
\text { porgy }\end{array}$} & $1: 190-256$ & $\begin{array}{l}\text { May } \\
\text { Jun } \\
\text { Jul } \\
\text { Aug } \\
\text { Sep }\end{array}$ & $\begin{array}{l}\text { Shelf edge, L } \\
\text { Shelf edge, L } \\
\text { Shelf edge, O } \\
\text { Shelf edge, O } \\
23 \text { mile }\end{array}$ \\
\hline & $2: 257-323$ & $\begin{array}{l}\text { May } \\
\text { Jun } \\
\text { Sep }\end{array}$ & $\begin{array}{l}\text { Shelf edge, } L \\
\text { Shelf edge, L } \\
23 \text { mile }\end{array}$ \\
\hline \multirow[t]{2}{*}{ Tomtate } & $1: 113-133$ & Sep & 23 mile \\
\hline & $2: 134-152$ & Sep & 23 mile \\
\hline
\end{tabular}

Inc. 1989) was used to determine relationships between $\delta X$ values and classification variables. $\mathrm{p}$-values less than or equal to 0.05 for Wilks' Lambda were considered significant. Discriminant analysis was also used to determine accuracy of species classificaton using 3 isotopic ratios. Finally, a new variable was created using the first principal component calculated on the correlation matrix of all 3 isotopes. The new variable was used to assess the variability within species due to size, location, and month of collection using 3-way ANOVA (GLM), with p-values less than or equal to 0.05 considered significant. Tukey's Studentized Range Test was used to determine which means were significantly different. 


\section{RESULTS}

$\delta^{13} \mathrm{C}$ values for fishes analyzed ranged from -18.3 to $-14.8 \% . \delta^{15} \mathrm{~N}$ values ranged from 9.1 to $12.2 \%$ for all fishes. $\delta^{34} \mathrm{~S}$ values ranged from 14.9 to $18.7 \%$. Tomtate had the lowest mean $\delta^{13} \mathrm{C}$ and $\delta^{15} \mathrm{~N}$ values, while spottail pinfish had the highest mean values for carbon and nitrogen (Table 2). Tomtate also had the lowest mean $\delta^{34} \mathrm{~S}$ value, but vermilion snapper had the highest mean $\delta^{34} \mathrm{~S}$ value.

The species variable was significantly related to isotope values (MANOVA, Wilks' Lambda $=0.221$, $\mathrm{p} \leq 0.0001$ ). Discriminant analysis correctly classified fishes into species 50 to $89 \%$ of the time using carbon and nitrogen isotope values (Table 3). This was

Table 2. Mean $\delta$ values ( $\% \pm \mathrm{SE}$ ) for species collected near hard bottom areas on the continental shelf. No. of individuals in parentheses

\begin{tabular}{|lccc|}
\hline Species & $\delta^{13} \mathrm{C}$ & $\delta^{15} \mathrm{~N}$ & $\delta^{34} \mathrm{~S}$ \\
\hline Round scad & $-17.3 \pm 0.10$ & $10.5 \pm 0.12$ & $17.1 \pm 0.18$ \\
Spottail pinfish & $(29)$ & $(29)$ & $(20)$ \\
& $-17.7 \pm 0.12$ & $11.0 \pm 0.15$ & $16.6 \pm 0.11$ \\
Vermilion snapper & $-17.4 \pm 0.04$ & $10.1 \pm 0.08$ & $(26)$ \\
& $(18)$ & $(18)$ & $17.3 \pm 0.15$ \\
Red porgy & $-16.2 \pm 0.16$ & $10.6 \pm 0.16$ & $(13)$ \\
Tomtate & $(17)$ & $(17)$ & $16.4 \pm 0.17$ \\
& $-15.9 \pm 0.20$ & $10.0 \pm 0.24$ & $15.8 \pm 0.26$ \\
& $(6)$ & $(6)$ & $(6)$ \\
\hline
\end{tabular}

Table 3. Results of discriminant analysis using $\delta^{13} \mathrm{C}$ and $\delta^{15} \mathrm{~N}$ values Numbers are percentage of fishes classified into a species by the model from the actual species classification

\begin{tabular}{|lccccc|}
\hline From $\mathbf{T}$ & $\begin{array}{c}\text { Round } \\
\text { scad }\end{array}$ & $\begin{array}{c}\text { Spottail } \\
\text { pinfish }\end{array}$ & $\begin{array}{c}\text { Vermilion } \\
\text { snapper }\end{array}$ & $\begin{array}{c}\text { Red } \\
\text { porgy }\end{array}$ & Tomtate \\
\hline Round scad & $55 \%$ & $21 \%$ & $17 \%$ & $7 \%$ & $0 \%$ \\
Spottail pinfish & $37 \%$ & $50 \%$ & $13 \%$ & $0 \%$ & $0 \%$ \\
Vermilion snapper & $11 \%$ & $0 \%$ & $89 \%$ & $0 \%$ & $0 \%$ \\
Red porgy & $23 \%$ & $0 \%$ & $12 \%$ & $59 \%$ & $6 \%$ \\
Tomtate & $0 \%$ & $0 \%$ & $0 \%$ & $17 \%$ & $83 \%$ \\
\hline
\end{tabular}

Table 4. Results of discriminant analysis using $\delta^{13} \mathrm{C}, \delta^{15} \mathrm{~N}$, and $\delta^{34} \mathrm{~S}$ values. Numbers are percentage of fishes classified into a species by the model from the actual species classification

\begin{tabular}{|c|c|c|c|c|c|}
\hline From $\nabla$ & $\begin{array}{l}\text { Round } \\
\text { scad }\end{array}$ & $\begin{array}{l}\text { Spottail } \\
\text { pinfish }\end{array}$ & $\begin{array}{l}\text { Vermilion } \\
\text { snapper }\end{array}$ & $\begin{array}{c}\text { Red } \\
\text { porgy }\end{array}$ & Tomtate \\
\hline Round scad & $60 \%$ & $25 \%$ & $15 \%$ & $0 \%$ & $0 \%$ \\
\hline Spottail pinfish & $23 \%$ & $69 \%$ & $4 \%$ & $4 \%$ & $0 \%$ \\
\hline Vermilion snapper & $8 \%$ & $0 \%$ & $92 \%$ & $0 \%$ & $0 \%$ \\
\hline Red porgy & $7 \%$ & $0 \%$ & $0 \%$ & $93 \%$ & $0 \%$ \\
\hline Tomtate & $0 \%$ & $0 \%$ & $0 \%$ & $17 \%$ & $83 \%$ \\
\hline
\end{tabular}

improved to 60 to $93 \%$ classification success by adding sulfur isotope data to the model (Table 4). This improvement was most dramatic in spottail pinfish $(+19 \%)$ and red porgy $(+34 \%)$. Round scad was most frequently misclassified, while red porgy and vermilion snapper were both accurately classified 92 to $93 \%$ of the time. When misclassified, fish were classied as round scad most frequently. No fish was ever isclassified as tomtate.

The 3-way ANOVA of the first principal component of sotopes (isotopic signature) showed a significant elationship with collection location in round scad milion snapper, and red porgy (Table 5). Isotopic signatures of round scad and red porgy from offshore in Long Bay were significantly different from round scad from the 23-mile ledge in Onslow Bay. Isotopic signatures of red porgy from offshore in Long Bay and from the 23-mile ledge in Onslow Bay were significantly different. Vermilion snapper from Onslow Bay differed significantly in isotopic signature from vermilion snappers collected in Long Bay. Isotopic signature of the 2 size classes of spottail pinfish were significantly different. Tomtate were only collected at 1 location on 1 day, so location and time variables could not be analyzed.

When 6 fish of each species and of similar size [within 24 to $63 \mathrm{~mm}$ Standard Length (SL, distance from snout to candal peduncle)] collected on the same day at 1 location are graphed using all 3 isotope ratios, species segregate into obvious groups (Fig. 1). When all fishes are graphed on the same axes, the segregation is not as apparent, but some grouping by species still occurs (Fig. 2). These clumps tend to correspond to the Tukey groupings derived from the ANOVA of the first principal component of the 3 isotopes. Groupings were: (1) round scad, spottail pinfish, and vermilion snapper; (2) red porgy and tomtate; and (3) spottail pinfish and red porgy. Only fish within the same group were not significantly different.

\section{DISCUSSION}

This study indicates that stable isotopes can be used to distinguish between fishes supported by different trophic pathways. Isotopic signatures of the 5 species from the North Carolina continental shelf were similar to those of fish 
Table 5. Results of 3-way ANOVA ( $F$-values and degrees of freedom) comparing effects of fish size, catch location, and month of collection on isotopic signatures of fishes collected off North Carolina, USA

\begin{tabular}{|c|c|c|c|}
\hline Species & Size class & Location & Month \\
\hline Round scad & $\begin{array}{c}F=1.19 \\
\mathrm{df}=1\end{array}$ & $\begin{array}{c}F=4.18^{\circ} \\
\mathrm{df}=2\end{array}$ & $\begin{array}{c}F=0.55 \\
\mathrm{df}=3\end{array}$ \\
\hline Spottail pinfish & $\begin{array}{c}F=11.68 \cdot \\
\mathrm{df}=1\end{array}$ & $\begin{array}{c}F=2.03 \\
\mathrm{df}=3\end{array}$ & $\begin{array}{c}F=2.08 \\
\mathrm{df}=4\end{array}$ \\
\hline Vermilion snapper & $\begin{array}{c}F=0.22 \\
\mathrm{df}=1\end{array}$ & $\begin{array}{c}F=6.10^{\circ} \\
\mathrm{df}=1\end{array}$ & $\begin{array}{c}F=0.71 \\
\mathrm{df}=2\end{array}$ \\
\hline Red porgy & $\begin{array}{c}F=3.30 \\
\mathrm{df}=1\end{array}$ & $\begin{array}{c}F=6.22 \\
\quad d f=2\end{array}$ & $\begin{array}{c}F=0.05 \\
\mathrm{df}=1\end{array}$ \\
\hline Tomtate & $\begin{array}{c}F=4.20 \\
\mathrm{df}=1\end{array}$ & - & - \\
\hline \multicolumn{4}{|c|}{$\cdot 0.01<p<0.05 ; \cdot 0.001<p<0.005$} \\
\hline
\end{tabular}

of similar feeding types from other locations. While similar, values for Decapterus punctatus and Rhomboplites aurorubens were outside ranges of $\delta^{13} \mathrm{C}$ for other planktivores (Table 6). These values were for fishes in more northern latitudes. $\delta^{13} \mathrm{C},{ }^{15} \mathrm{~N}$, and ${ }^{34} \mathrm{~S}$ values for all 5 species fall within ranges found for other fishes by Fry et al. (1982) and others. $\delta^{15} \mathrm{~N}$ values indicate that all 5 species are probably feeding within 1 trophic level (secondary consumers). Although carbon and nitrogen isotope values were able to separate the 5 species, the addition of sulfur values increased accuracy of separation. This was evident in the discriminant analysis. Accuracy of separation increased as much as $34 \%$ after the addition of sulfur values. Fry \& Sherr (1989) suggest that $\delta^{34} \mathrm{~S}$ should allow differentiation between benthic and pelagic feeders because benthic feeders will retain the lower $\delta^{34} \mathrm{~S}$ values of benthic primary producers. In fact, the 3 benthic feeders had significantly lower $\delta^{34} \mathrm{~S}$ values compared to the 2 pelagic feeders (Table 2). Although carbon values were different for the species, sulfur was crucial in distinguishing between the pelagic and benthic food sources.

Sediment with attached microalgae from Onslow Bay had mean $\delta^{13} \mathrm{C}$ values of $-19.6 \%(n=8)$ (L. B. Cahoon unpubl.). Particulate organic matter from offshore in the Gulf of Mexico had mean $\delta^{13} \mathrm{C}$ values of $-21.7 \pm 1.6 \%(n=87)$ (Fry \& Sherr 1989). This environment is similar to the warm temperate environment off the coast of the Carolinas. Similar data are not available for offshore Onslow Bay. Fish carbon values are consistent with these trophic base numbers. Benthic feeders had $\delta^{13} \mathrm{C}$ values that were slightly more enriched (less negative) than their pelagic counterparts.

Accordingly, isotope signatures grouped fishes into feeding types, as predicted from knowledge of feeding behavior and gut contents. Vermilion snapper and round scad both feed on pelagic food items. Hales (1987) and Donaldson (1991) reported a diet of holozooplankton for round scad. Grimes (1979) described vermilion snappers as foraging for pelagic prey. The signatures of these 2 species were not significantly different from each other, but did differ significantly from the isotopic signatures of tomtate and red porgy. Tomtate are known to feed upon demersal zooplankton (Bolden 1990), whereas red porgy feed almost entirely on obligate benthic organisms and some demersal items (Manooch 1977). The signatures of these demersal fishes were not significantly different from each other, but were different from those of round scad and vermilion snapper.

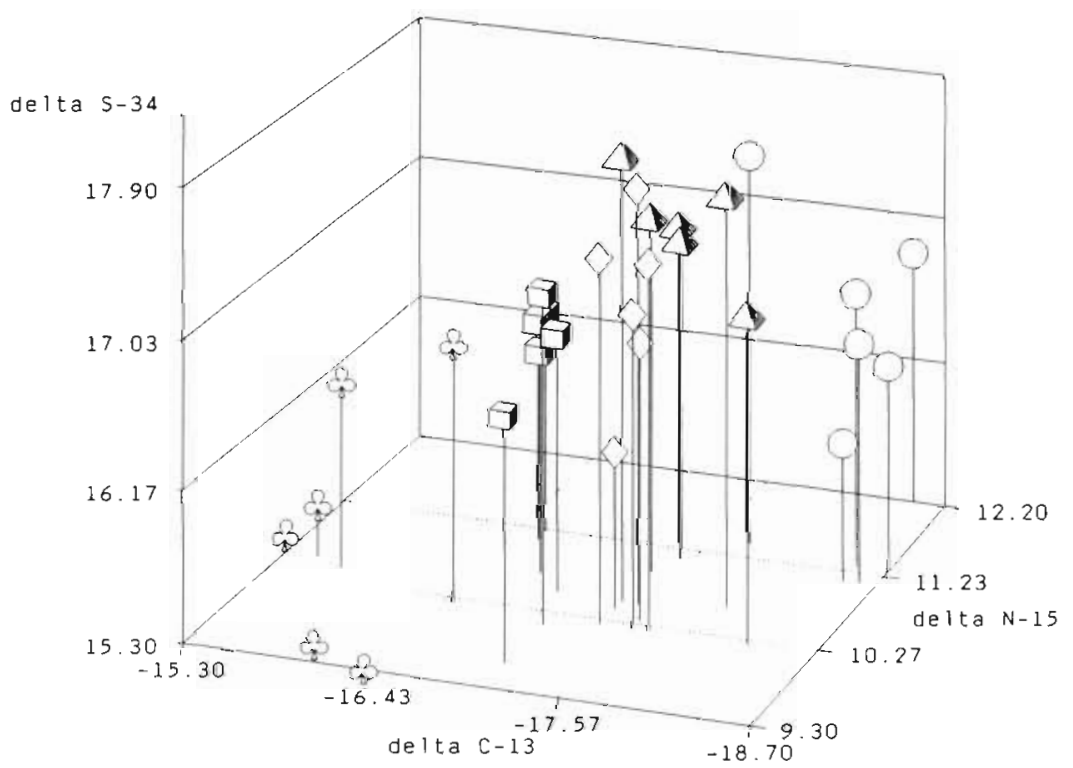

Fig. 1. Plot of stable isotope ratios for 6 individual specimens from each species collected on the same day at the same location. Symbols represent species: $\Delta=$ round scad Decapterus punctatus $(\mathrm{n}=6) ; \mathrm{O}=$ spottail pinfish Diplodus holbrooki $(\mathrm{n}=6) ; 0=$ vermilion snapper Rhomboplites aurorubens $(\mathrm{n}=6)_{\text {; }}$ $\square=$ red porgy Pagrus pagrus $(\mathrm{n}=6)_{i}$ and $\xi=$ tomtate Haemulon aurolineatum $(n=6)$ 
Fig. 2. Plot of stable isotope ratios for individual specimens. Symbols represent species: Symbols represent species: $\Delta=$ round scad Decapterus punctatus ( $\mathrm{n}=20$ ); $\mathrm{O}=$ spottail pinfish Diplodus holbrooki $(\mathrm{n}=26) ; \vartheta=$ vermilion snapper Rhomboplites aurorubens $(\mathrm{n}=13) ; \quad \boldsymbol{O}=$ red porgy Pagrus pagrus $(\mathrm{n}=14)$; and $\zeta=$ tomtate Haemulon aurolineatum $(\mathrm{n}=6)$

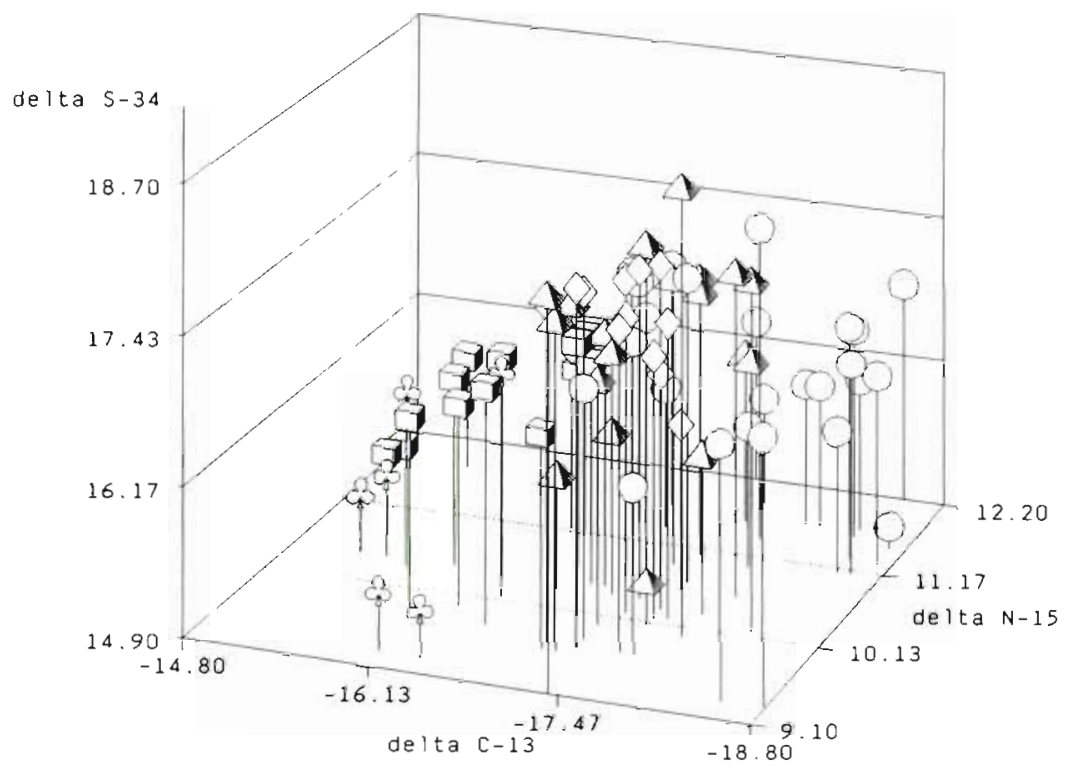

Also, $\delta^{13} \mathrm{C}$ values for the pinfish are enriched relative to those reported for other algivores (Table 6). In addition, spottail pinfish are not morphologically suited for digestion of plant material as they have a relatively short gut length (Pike 1991) that falls into Al-Hussaini's (1947) crustacean-feeding carnivore group.

No significant differences were found in the isotopic signatures of fishes collected in different months. Fry \& Wainright (1991) found that rapidly growing diatoms associated with spring and summer blooms on George's Bank were relatively enriched with ${ }^{13} \mathrm{C}$. Either the strong seasonal variability Fry \& Wainright (1991) observed on George's Bank does not occur off North Carolina, or seasonal differences in planktonic $\delta^{13} \mathrm{C}$ values were not reflected in white swimming muscle of fish. Turnover times are long for swimming muscle; therefore, diet is integrated over time. If seasonal variation in diatom signature is conserved in higher trophic levels in Onslow Bay, it is probably evident in organs with rapid turnover times, such as blood and liver.

Variability within species is largely from differing locations. Isotopic signatures of red porgy, vermilion snapper, and round scad varied significantly with location. Manooch (1977), Grimes (1979), and Donaldson (1991) all found stomach contents of the respective fish to vary in different locations. These fishes are foragers feeding on any available food found in the habitat, rather than eating one item selectively. Differences in stomach contents from location to location are probably a result of food availability at each location. 
Acknowledgements. This study was supported by the Cooperative Institute of Fisheries Oceanography, a grant-in-aid from Sigma $\mathrm{Xi}$, and the Lerner-Gray Fund for Marine Research through the American Museum of Natural History. We thank Dr I. E. Clavijo, Dr D. G. Lindquist, Dr J. R. Pawlik, Dr T. H. Shafer, L. Pike, P. Donaldson, G. Beretich, A McDonald, T. Grater, W. Grater, K. Ogborn, E. Thomas, P. Thomas, and M. Thomas. We also thank Dr B. Fry and H. Garritt for completing the isotope analyses.

\section{LITERATURE CITED}

Al-Hussaini, A. H. (1947). The feeding habits and the morphology of the alimentary tract of some teleosts living in the neighborhood of the marine biological station, Ghardaqa, Red Sea. Publication No. 5 of the Marine Biological Station, Gharda (Red Sea)

Bolden, S. (1990). Abundance, diet and foraging migrations of the tomtate (Haemulon aurolineatum) on an artificial and a natural reef in Onslow Bay, North Carolina. M.Sc. thesis, University of North Carolina, Wilmington

Cahoon, L. B., Cooke, J. E. (1992). Benthic microalgal production in Onslow Bay, North Carolina, USA. Mar. Ecol. Prog. Ser. 84: 185-196

Cahoon, L. B., Redman, R. S., Tronzo, C. R. (1990). Benthic microalgal biomass in sediments of Onslow Bay, North Carolina, USA. Estuar. coast. Shelf Sci. 31: 805-816

DeNiro, M. J., Epstein, S. (1978). Influence of diet on the distribution of carbon isotopes in animals. Geochim. Cosmochim. Acta 42: 495-506

Donaldson, P. (1991). The diet of round scad (Decapterus punctatus) on a natural and an artificial reef in Onslow Bay, N.C. M.Sc. thesis, University of North Carolina, Wilmington

Fry, B. (1984). ${ }^{13} \mathrm{C}^{12} \mathrm{C}$ ratios and the trophic importance of algae in Florida Syringodium filiforma seagrass meadows. Mar. Biol. 79: 11-19

Fry, B. (1988). Food web structure on Georges Bank from stable $\mathrm{C}, \mathrm{N}$, and $\mathrm{S}$ isotopic compositions. Limnol. Oceanogr. 33: 1182-1190

Fry, B., Lutes, R., Northam, M., Parker, P. L., Ogden, J. (1982). $\mathrm{A}^{13} \mathrm{C} /{ }^{12} \mathrm{C}$ comparison of food webs in Caribbean seagrass meadows and coral reefs. Aquat. Bot. 14:389-398

Fry, B., Parker, P. L. (1979). Animal diet in Texas USA seagrass meadows carbon-13 evidence for the importance of benthic plants. Estuar. coast. mar. Sci. 8: 499-510

This article was submitted to the editor
Fry, B., Sherr, E. B. $(1989) . \delta^{13} \mathrm{C}$ measurements as indicators of carbon flow in marine and freshwater ecosystems. In: Rundel, P. W., Ehleringer, J. R., Nagy, K. A. (eds.) Stable isotopes in ecological research. Springer-Verlag Publishing. New York, p. 196-229

Fry, B., Wainright, S. C. (1991). Diatom sources of ${ }^{13} \mathrm{C}$-rich carbon in marine food webs. Mar. Ecol. Prog. Ser. 76: $149-157$

Goering, J., Alexander, V., Haubenstock, N. (1990). Seasonal variability of stable carbon and nitrogen isotope ratios of organisms in a North Pacific Bay. Estuar. coast. Shelf Sci. 30: $239-260$

Grimes, C. B. (1979). Diet and feeding ecology of the vermilion snapper, Rhomboplites aurorubens (Cuvier) from North Carolina and South Carolina waters. Bull. mar. Sci. 29: $53-61$

Hales, L. S. (1987). Distribution, abundance, reproduction, food habits, age, and growth of round scad, Decapterus punctatus, in the South Atlantic Bight. Fish. Bull. U.S. 85: $251-268$

Hay, M. E., Sutherland, J. P. (1988). The ecology of rubble mound structures of the South Atlantic Bight: a community profile. U.S. Fish Wildl. Serv. biol. Rep. 85

Manooch, C. S. (1977). Foods of the red porgy, Pagrus pagrus Linnaeus (Pisces: Sparidae), from North Carolina and South Carolina. Bull. mar. Sci. 27: 776-787

Pike, L. (1991). The feeding ecology of spottail pinfish (Pisces: Sparidae): a comparison between a natural and artificial reef in Onslow Bay, North Carolina. M.Sc. thesis, University of North Carolina, Wilmington

Rau, G. H., Mearns, A. J., Young, D. R., Olson, R. J., Schafer, H. A., Kaplan, I. R. (1983). Animal ${ }^{13} \mathrm{C} /{ }^{12} \mathrm{C}$ correlates with trophic level in pelagic food webs. Ecology 64: $1314-1318$

SAS Institute Inc. (1989). Version $6.06 \mathrm{edn}$. SAS Institute Inc., Cary, NC

Schneider, C. W. (1976). Spatial and temporal distributions of benthic algae on the continental shelf of the Carolinas. Bull. mar. Sci. 26: 133-151

Tieszen, L. L., Boutton, T W., Tesdahl, K. G., Slade, N. A. (1983). Fractionation and turnover of stable carbon isotopes in animal tissues: implications for $\delta^{13} \mathrm{C}$ analysis of diet. Oecologia 57: 32--37

Tronzo, C. (1989). The ecology of demersal zooplankton in Onslow Bay, N.C. M.Sc. thesis, University of North Carolina, Wilmington

Manuscript first received: December 9, 1992

Revised version accepted: February 15, 1993 